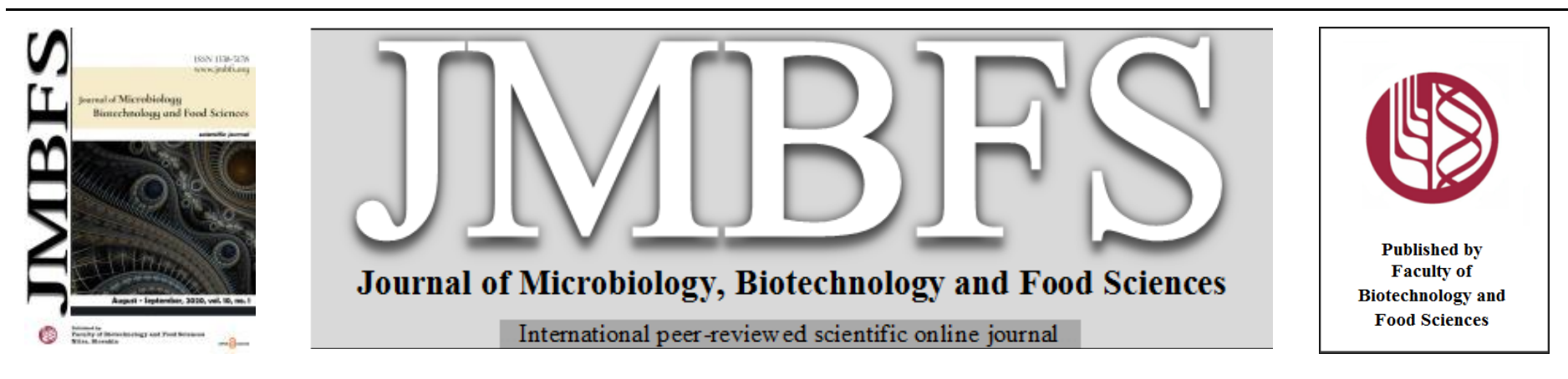

\title{
A SIMPLE METHOD FOR HARVESTING Trichoderma asperellum SPORES
}

\section{Domenico Pavone-Maniscalco $*^{1}$, Massiel Pinto ${ }^{1}$, Renny Pacheco-Calderón ${ }^{2}$, Douglas Mora ${ }^{1}$, Carmen Andara ${ }^{2}$, Anakarina Bello ${ }^{2}$, Maira Hernández ${ }^{1}$, María Alejandra Correa ${ }^{l}$ \& Oscar Valbuena ${ }^{l}$}

\section{Address(es):}

${ }^{1}$ Centro de Biotecnología Aplicada (CBA), Departamento de Biología, Facultad de Ciencias y Tecnología, Universidad de Carabobo, Campus de Bárbula, Municipio Naguanagua, Estado Carabobo, Venezuela. Phone: +584244737054

${ }^{2}$ Centro de Zoología Aplicada (CEZA), Departamento de Biología, Facultad de Ciencias y Tecnología, Universidad de Carabobo, Campus de Bárbula, Municipio

Naguanagua, Estado Carabobo, Venezuela.

*Corresponding author: dfpavone@gmail.com

doi: 10.15414/jmbfs.2020.10.1.65-67

\section{ARTICLE INFO}

Received 23. 9. 2018

Revised 8. 3. 2020

Accepted 12. 3. 2020

Published 1. 8. 2020

Short communication

OPEN $\partial_{\text {ACCESS }}$

\section{ABSTRACT}

The fungus Trichoderma asperellum has a great potential to be used as biocontrol agent against plant pathogens in field. For this purpose it is necessary to optimize mass production on an industrial scale. This work proposes a method for the recovery and concentration of T. asperellum spores. The addition of the fertilizer Urfos $44^{\circledR}$, decreased $\mathrm{pH}$ value of spore suspension from 6.31 to 1.76. This condition allowed spores to flocculate in few hours, rendering a more concentrated suspension by a factor of $6-7$. Spore viability did not significantly decreased in 72 hours under these conditions. These results will contribute to obtain more concentrated products based on T. asperellum using a fast and low cost method.

Keywords: Solid state fermentation, flocculation, aggregation, Urfos $44^{\circledR}$, urea, phosphoric acid

\section{INTRODUCTION}

The fungus Trichoderma asperellum (Ascomycota) is a well-known biocontrol agent in agriculture (Wu et al., 2017; Rosmana et al., 2016; Li et al., 2016; El Komy et al., 2015; Elsharkawy et al., 2013; Mbarga et al., 2013; Segarra et al., 2010). The industrial production of T. asperellum is generally based on solid state fermentations (SSF), in which substrates as rice or maize are usually used. In our laboratory, spore recovery after fermentation is carried out by washing fermented material with water, followed by a concentration step. There are several methods to concentrate spores, such as centrifugation, filtration and decantation, among others; however such methods could be expensive or time consuming.

Flocculation is a useful method for harvesting biomass in yeast and microalgae industry (Kim et al., 2017; Vallejo et al., 2013; Vandamme et al., 2013; Schlesinger et al., 2012; Soares, 2010), but there is no report in literature using this method for harvesting Trichoderma spores.

Urfos $44^{\circledR}$ is a fertilizer containing urea and phosphorous, when dissolved in water forms urea and phosphoric acid as described in equation 1, resulting in the decreasing of $\mathrm{pH}$ values.

\section{$\left[\mathrm{H}_{3} \mathrm{PO}_{4}:\left(\mathrm{NH}_{2}\right)_{2} \mathrm{CO}\right]_{\text {crystal }} \longrightarrow \quad \mathrm{H}_{3} \mathrm{PO}_{4}+\left(\mathrm{NH}_{2}\right)_{2} \mathrm{CO} \quad$ (Eq 1)}

In this work, the use of Urfos $44^{\circledR}$ as a flocculant agent for harvesting $T$. asperellum spores will be described, as well as, its effect on some physicochemical parameters and viability of spore suspension.

\section{MATERIALS AND METHODS}

\section{Biological material}

The strain of Trichoderma asperellum used (TV190), was isolated from corn field soil in Monagas State, Venezuela, and identified by molecular analysis (Pavone \& Dorta, 2015). It was maintained by alternated culture on potato dextrose agar (PDA) and sterilized soil.

\section{Flocculant agent}

Urfos $44^{\circledR}$ produced by Tripoliven C.A., Carabobo, Venezuela (www.tripoliven.com/documentos/URFOS-44.ppt), is a fertilizer used in several agricultural crops. The composition and some physicochemical characteristics of Urfos $44^{\circledR}$ are described in Table I.

Table I Composition and some physicochemical characteristics of Urfos $44^{\circledR}$

\begin{tabular}{ll}
\hline Composition/ Physicochemical Characteristic & Value \\
\hline Phosphorous, $\mathrm{P}_{2} \mathrm{O}_{5}$ & $44 \%$ \\
Nitrogen, N & $17 \%$ \\
$\mathrm{pH}($ solution at $1 \% \mathrm{w} / \mathrm{v})$ & $1.7-1.9$ \\
Conductivity, $\mathrm{CE}(1 \mathrm{~g} / \mathrm{L})$ & $0.84 \mathrm{dS} / \mathrm{m}$ \\
Solubility $20^{\circ} \mathrm{C}$ & $960 \mathrm{~g} / \mathrm{L} \mathrm{H}_{2} \mathrm{O}$ \\
Chemical purity (dry base) & $>99 \%$ \\
\hline
\end{tabular}

\section{Production of T. asperellum}

The production of $T$. asperellum was based on a solid state fermentation using maize or rice. The substrate (150 g), hydrated (50\% dry basis) in cellophane bags $(20 \times 30 \mathrm{~cm})$, was cooked by wet heat for two hours. A $10^{7}$ spores $/ \mathrm{mL}$ suspension of the fungus $(10 \mathrm{~mL})$ was inoculated in each bag, mixed and incubated at $27 \pm 2$ ${ }^{\circ} \mathrm{C}$ for 5-6 days. After sporulation, fermented material was washed twice using potable water. The resulting spore suspension was passed through a sieve with $1.5 \mathrm{~mm}$ pores and reserved for subsequent experiments.

\section{Effect of Urfos $44^{\circledast}$ on $\mathrm{pH}$ suspension, spore viability and concentration}

Spore suspension was transferred to $1 \mathrm{~L}$ bottles adding Urfos $44^{\circledR}$ at different concentrations $(0 ; 0.1 ; 0.5$ and $1 \% \mathrm{w} / \mathrm{v})$. The bottles were shaken by handle and five samples were taken to measure $\mathrm{pH}$ and initial spore concentration. After 24 $\mathrm{h}$, spore concentration and volume occupied by spores were determined. Spore concentration was determined using a Neubauer chamber and $\mathrm{pH}$ was measured using a pH meter (Sper Scientific). Finally, spore viability was determined at different times $(0,24,48$ and $72 \mathrm{~h})$ and storage conditions $\left(5^{\circ} \mathrm{C}\right.$ or $\left.25^{\circ} \mathrm{C}\right)$, by cultivating dilutions $\left(10^{-7}\right.$ and $\left.10^{-8}\right)$ of spore suspensions on PDA plates (three replicates). Results were expressed in $\mathrm{CFU} / \mathrm{mL}$ and analyzed through ANOVA to determine statistical differences using the Program Statistix v.8. All experiments were repeated twice. 


\section{RESULTS \& DISCUSION}

\section{Concentration and suspension $\mathrm{pH}$}

One of the most important effects of Urfos $44^{\circledR}$ on spore suspension is the decreasing of $\mathrm{pH}$. Table II resumes $\mathrm{pH}$ values for spore suspension at different Urfos $44^{\circledR}$ concentrations. Suspensions without Urfos $44^{\circledR}$ presented $\mathrm{pH}$ values of 6.31, whereas increasing Urfos $44^{\circledR}$ concentration to $1 \% \mathrm{w} / \mathrm{v}$, decreased $\mathrm{pH}$ to 1.76. In suspensions without Urfos $44^{\circledR}$ or $0.1 \% \mathrm{w} / \mathrm{v}$, volume occupied by spores did not vary $(975 \mathrm{~mL})$. However, when adding Urfos $44^{\circledR}$ at 0.5 or $1 \% \mathrm{w} / \mathrm{v}$, volume occupied by spore after $24 \mathrm{~h}$, decreased to $150 \mathrm{~mL}$. Under these conditions, aggregation and flocculation of spores occurred in few hours Initially, spore concentration was $2.81 \times 10^{8}$ spore $/ \mathrm{mL}$ (value not shown in Table II), whereas when adding Urfos $44^{\circledR}$ at 0.5 and $1 \% \mathrm{w} / \mathrm{v}$, spore concentration reached $1.83 \times 10^{9}$ and $2.12 \times 10^{9}$ spore $/ \mathrm{mL}$, respectively (Table II). The spore concentration was 6-7 times higher than the untreated spore suspension. Finally, a brown color only in treatments without Urfos $44^{\circledR}$ at $25^{\circ} \mathrm{C}$ was evident after 24 48 hours, suggesting an oxidation process and a protective effect of Urfos $44^{\circledR}$.

Table II Effect of Urfos $44^{\circledR}$ on $\mathrm{pH}$, volume of spores and spore concentration of T. asperellum

\begin{tabular}{lccc}
$\begin{array}{l}\text { Urfos } 44^{\circledR} \\
\text { Concentratio } \\
\mathrm{n}(\% \mathrm{w} / \mathrm{v})\end{array}$ & $\mathrm{pH}$ & $\begin{array}{c}\text { Volume }(\mathrm{mL}) \\
\text { occupied by } \\
\text { spores after } 24 \mathrm{~h}\end{array}$ & $\begin{array}{c}\text { Concentration (Spores } / \mathrm{mL}) \\
(24 \mathrm{~h})\end{array}$ \\
\hline 0 & $6.31 \pm 0.013$ & 975 & $1.01 \times 10^{8} \pm 1.87 \times 10^{7} \mathrm{a}$ \\
0.1 & $4.53 \pm 0.008$ & 975 & $1.32 \times 10^{8} \pm 1.09 \times 10^{7} \mathrm{a}$ \\
0.5 & $2.20 \pm 0.009$ & 150 & $1.83 \times 10^{9} \pm 2.53 \times 10^{8} \mathrm{~b}$ \\
1 & $1.76 \pm 0.011$ & 150 & $2.12 \times 10^{9} \pm 2.08 \times 10^{8} \mathrm{~b}$ \\
\hline
\end{tabular}

It was demonstrated that the addition of Urfos $44^{\circledR}$ to $T$. asperellum spore suspension accelerates flocculation. Under these conditions, spores maintained its viability at least for 72 hours. This is the first report of flocculation of $T$. asperellum spores using Urfos $44^{\circledR}$. However, the molecular mechanism involved in this process is unknown; it will be necessary more studies to understand the role of $\mathrm{pH}$ decreasing, urea, phosphoric acid or other microelements present in suspension.

\section{Viability of T. asperellum spores in Urfos $44^{\circledR}$ suspensions}

High spore viability in a biocontrol agent is crucial to obtain adequate control in field. For this reason, all methods used to produce and recovery spores must be suitable to maintain viability. In Figure 1, viability of $T$. asperellum spores at different Urfos $44^{\circledR}$ concentrations and storage conditions is shown. Statistical analysis demonstrated that viability did not change significantly between 0 and 72 hours in all treatments, with p-values of $\mathrm{U} 25=0.86$, W $25=0.73, \mathrm{U} 5=0.47$ and $\mathrm{W} 5=0.86$.

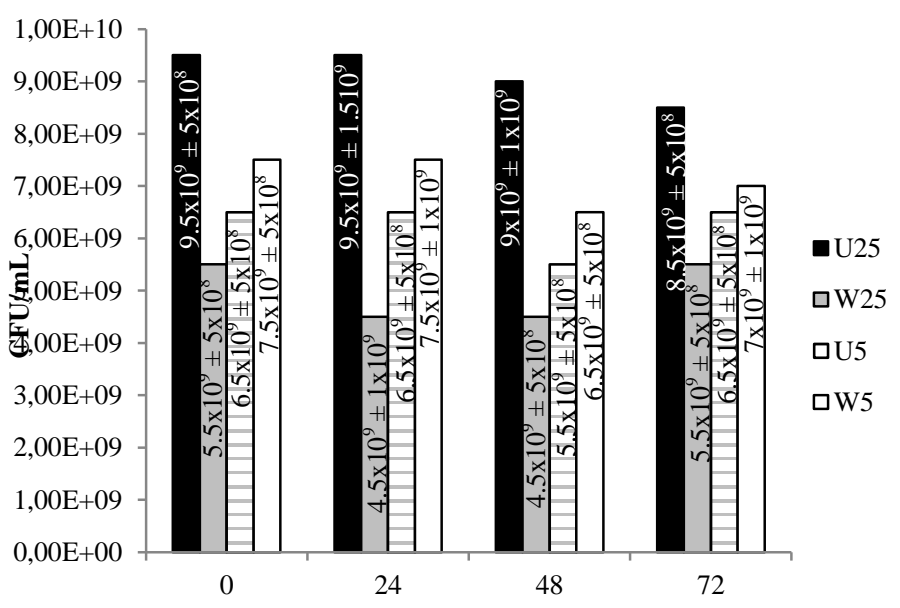

Time (hours)

Figure 1 Viability $(\mathrm{CFU} / \mathrm{mL})$ of $T$. asperellum spores in Urfos $44^{\circledR}$ suspension $(0.5 \% \mathrm{w} / \mathrm{v})$.

U25: Urfos $44^{\circledR}$ suspension at $25^{\circ} \mathrm{C}$; W25: Water suspension at $25^{\circ} \mathrm{C}$; U5: Urfos $44^{\circledR}$ suspension at $5^{\circ} \mathrm{C}$; W5: Water suspension at $5^{\circ} \mathrm{C}$.

In yeasts, there are many reports of flocculation as a common process used in industry. Several mechanism of flocculation have been described in Saccharomyces cerevisiae, including: (a) cell wall charge and hydrophobicity: at physiological $\mathrm{pH}$ values, $S$. cerevisiae cell wall bears a net negative charge due to the ionization of carboxyl and phosphodiester groups, which drives repulsion of charges reducing cell aggregation. Therefore, the reduction of cell charge should facilitate yeast flocculation. Additionally, cell-surface is partially responsible by the triggering of flocculation of brewing strains (Smit et al., 1992; Straver et al., 1993; Speers et al., 2006; cited by Soares, 2010); (b) Lectin theory, in which a specific lectin-like protein interacts with carbohydrate residues of $\square$-mannans and (c) Flo1: cell surface proteins present in yeast related to the flocculation process (Soares, 2010). The cell wall composition of Trichoderma pseudokoningii mycelium was determined by Jennah et al., (1982), whom treating it sequentially with enzymes detected a layered structure comprising glucan, protein/glycoprotein, and chitin. For the genus Trichoderma there is no report of Flo1 gen on GenBank, whereas it has been reported in yeasts (Van Mulders et al., 2010) and some species of the filamentous fungus Metarhizium rileyi (Shang et al., 2016).

Culture filtrates and mycelial extracts of two mycoparasitic Trichoderma species were tested for the presence of lectins, by haemagglutination with human and marsupial erythrocytes (Neethling \& Nevalainen, 1996). In Trichoderma viride, haemagglutinating activity was present in both mycelial extracts and culture filtrate. While secreted lectins were only detected after 6 days of growth, the presence of mycelium-associated lectins was first noted in 3 day old cultures. Agglutinating activity was also demonstrated in the mycelium of 6 to 13 days old cultures of Trichoderma harzianum. This is the first report on the occurrence of lectins in Trichoderma spp. Spores of Trichoderma harzianum have been harvested for seed application by scrapping from PDA plates, obtaining 11-12 $\log 10 \mathrm{CFU} / \mathrm{g}$ (Singh \& Nautiyal, 2012).

A $\mathrm{pH}$ increase for harvesting microalgae have induced flocculation with efficiency up to $90 \%$ for freshwater microalgae (Chlorella vulgaris, Scenedesmus sp. and Chlorococcum sp.) and marine microalgae (Nannochloropsis oculata and Phaeodactylum tricornutum) (Wu et al., 2012). In this case, magnesium in the hydrolyzed growth medium drives the formation of magnesium hydroxide precipitate, which coagulated microalgal cells by sweeping flocculation and charge neutralization. Additionally, the microalgal biomass concentration and released polysaccharide from microalgae could influence the flocculation efficiencies. It has been proposed that alkaline flocculants neutralize the repelling surface charges of algal cells, allowing coalescence into a floc. Flocculation can also be due to multi-valent cross-linking or co-precipitation with phosphate, magnesium and/or calcium (Schlesinger et al., 2012).

In microalgal cultures, flocculation often occurs spontaneously when $\mathrm{pH}$ increases above 9 (autoflocculation) as a result of photosynthetic $\mathrm{CO}_{2}$ depletion. As stated below, this process is associated with the formation of calcium or magnesium precipitates, which can induce flocculation through charge neutralization and/or sweeping flocculation. High phosphate concentrations are required for this type of flocculation to occur (Vandamme et al., 2013). For harvesting Chlorella sp biomass, a new flocculation approach utilizing metal coagulant $\left(\mathrm{Fe}_{2}\left(\mathrm{SO}_{4}\right)_{3}\right)$ and sulfuric acid $\left(\mathrm{H}_{2} \mathrm{SO}_{4}\right)$ is actually used. The method induces a reduction of $\mathrm{pH}$ which releases precipitates attached to the microalgae (Kim et al., 2017).

In fungal biocontrol formulation for industry, the methodology to harvest and concentrate spores is a key step. Current methods have an important impact on sale prices due to reactive, high cost equipment or time consuming processes. The method proposed in this work utilizes a very inexpensive agricultural commodity in a fast and simple way to concentrate spores of $T$. asperellum, reaching a gel consistence from which it is possible to formulate directly or initiate a complete dehidratation process.

Concentrated spore suspension of T. asperellum obtained by the above described method, was air dried and mixed with starch, and finally processed to obtain a granular formulation with $2 \times 10^{9}$ spore/g and commercialized in bags with 50 $\mathrm{g} / \mathrm{ha}$. Albeit, this product acts efficiently in field, a more detailed study related to the effects of Urfos $44^{\circledR}$ on spore physiology and presence of contaminants is necessary.

\section{CONCLUSIONS}

Our results suggest that the addition of Urfos $44^{\circledR}$ to $T$. asperellum spore suspension is a suitable, fast and low-cost method to concentrate spores which does not affect its viability. However, the effect of the flocculation agent on other physiological characteristics of $T$. asperellum, as well as, the mechanism by which flocculation is induced $(\mathrm{pH}$, presence of urea, phosphoric acid, etc.), remains to be determined.

Acknowledgment: Authors would like to thank Tecnovita C.A. and Agromarketing C.A. for supplies used in this work.

\section{REFERENCES}

Elsharkawy, M., Shimizu, M., Takahashi, H., Ozaki, K., Hyakumachi, M. (2013). Induction of systemic resistance against cucumber mosaic virus in Arabidopsis thaliana by Trichoderma asperellum SKT-1. The Plant Pathology Journal, 29(2), 193-200. Doi: https://doi.org/10.5423/PPJ.SI.07.2012.01.

El Komy, M., Saleh, A., Eranthodi, A., Molan, Y. (2015). Characterization of novel Trichoderma asperellum isolates to select effective biocontrol agents 
against tomato Fusarium wilt. The Plant Pathology Journal, 31(1), 50-60. Doi: https://dx.doi.org/10.5423\%2FPPJ.OA.09.2014.0087.

Jennah, M., Davison, B., Boothby, D. (1982). Layered structure of Trichoderma cell walls. Archives of Microbiology, 133(4), 330-331.

Kim, D., Lee, K., Lee, J., Lee, Y., Han, J., Park, J., Oh, Y. (2017). Acidifiedflocculation process for harvesting of microalgae: coagulant reutilization and metal-free-microalgae recovery. Bioresource Technology, 239, 190-196. Doi: https://doi.org/10.1016/j.biortech.2017.05.021.

LI Y., SUN R., YU J., SARAVANAKUMAR K., CHEN J. 2016. Antagonistic and biocontrol potential of Trichoderma asperellum ZJSX5003 against the maize stalk rot pathogen Fusarium graminearum. Indian Journal of Microbiology, 56(3), 318-27. Doi: https://dx.doi.org/10.1007\%2Fs12088-016-0581-9.

Mbarga, J., Ten Hoopen G., Begoude, A., Tondje, P., Kuate, J., Ambang, Z., Amougou, A., Schiffers, B. (2012). Efficacy of Trichoderma asperellum oil formulations on the control of cocoa black pod disease (Phytophthora megakarya). Communications in Agricultural and Applied Biological Sciences 77(3), 65-73.

Neethling, D., Nevalainen, H. (1996). Mycoparasitic species of Trichoderma produce lectins. Canadian Journal of Microbiology, 42(2), 141-146. Doi: https://doi.org/10.1139/m96-022.

Pavone, D., Dorta, B. (2015). Diversidad del hongo Trichoderma spp. en plantaciones de maíz de Venezuela. Interciencia, 40(1), 23-31.

Rosmana, A., Nasaruddin, N., Hendarto, H., Hakkar, A., Agriansyah, N. (2016). Endophytic Association of Trichoderma asperellum within Theobroma cacao suppresses vascular streak dieback incidence and promotes side graft growth Mycobiology. 44(3), 180-186. Doi: https://doi.org/10.5941/MYCO.2016.44.3.180.

Santos, A., García, M., Cotes, A., Villamizar, L. (2012). The effect of the formulation on the shelf-life of biopesticides based on two Colombian isolates of Trichoderma koningiopsis Th003 and Trichoderma asperellum Th034. Revista Iberoamericana de Micologia, 29(3), 150-156. Doi: https://doi.org/10.1016/j.riam.2011.11.002.

Schlesinger, A., Eisenstadt, D., Bar-Gil, A., Carmely, H., Einbinder, S., Gressel, J. (2012). Inexpensive non-toxic flocculation of microalgae contradicts theories; overcoming a major hurdle to bulk algal production. Biotechnology Advances, 30, 1023-1030. Doi: https://doi.org/10.1016/j.biotechadv.2012.01.011.

Segarra, G., Casanova, E., Avilés, M., Trillas, I. (2010). Trichoderma asperellum strain T34 controls Fusarium wilt disease in tomato plants in soilless culture through competition for iron. Microbial Ecology, 59(1), 141-149. Doi https://doi.org/10.1007/s00248-009-9545-5.

Shang, Y., Xiao, G., Zheng, P., Cen, K., Zhan, S., Wang, C. (2016). Divergent and convergent evolution of fungal pathogenicity. Genome Biology and Evolution, 8(5), 1374-87. Doi: https://doi.org/10.1093/gbe/evw082.

Singh, P., Nautiyal, C. (2012). A novel method to prepare concentrated conidial biomass formulation of Trichoderma harzianum for seed application. Journal of Applied Microbiology, 113, 1442-1450. Doi: https://doi.org/10.1111/j.13652672.2012.05426.x.

Soares, E. (2010). Flocculation in Saccharomyces cerevisiae: A review. Journal of Applied Microbiology, 110, 1-18. Doi: https://doi.org/10.1111/j.13652672.2010.04897.x.

Vallejo, J., Sánchez-Pérez, A., Martínez, J., Villa, T. (2013). Cell aggregations in yeasts and their applications. Applied Microbiology and Biotechnology. 97, 2305-2318. Doi: https://doi.org/10.1007/s00253-013-4735-y.

Van Mulders, S., Ghequire, M., Daenen, L., Verbelen, P., Verstrepen, K., Delvaux, F. (2010). Flocculation gene variability in industrial brewer's yeast strains. Applied Microbiology and Biotechnology, 88 (6), 1321-1331. Doi: https://doi.org/10.1007/s00253-010-2843-5.

Vandamme, D., Foubert, I., Muylaert, K. (2013). Flocculation as a low-cost method for harvesting microalgae for bulk biomass production. Trends in Biotechnology, 31(4), 233-239. Doi https://doi.org/10.1016/j.tibtech.2012.12.005.

Wu, Q., Sun, R., Ni, M., Yu, J., Li, Y., Yu, C., Dou, K., Ren, J., Chen, J. (2017) Identification of a novel fungus, Trichoderma asperellum GDFS1009, and comprehensive evaluation of its biocontrol efficacy. PLoS One, 12(6), e0179957. Doi: https://doi.org/10.1371/journal.pone.0179957.

Wu, Z., Zhu, Y., Huang, W., Zhang, C., Li, T., Zhang, Y., Li, A. (2012). Evaluation of flocculation induced by $\mathrm{pH}$ increase for harvesting microalgae and reuse of flocculated medium. Bioresource Technology, 110, 496-502. Doi: https://doi.org/10.1016/j.biortech.2012.01.101. 